Primljen / Received: 31.12.2013. Ispravljen / Corrected: 21.6.2014.

Prihvaćen / Accepted: 15.7.2014. Dostupno online / Available online: 1.8.2014.

\title{
Trends of indicators of hydrological alterations
}

\section{Authors:}

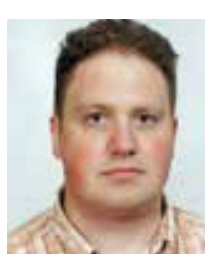

Darko Barbalić, BSc. CE

Hrvatske vode

Department of water management darkob@voda.hr

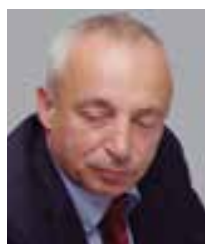

Prof. Neven Kuspilić, PhD. CE

University of Zagreb

Faculty of Civil Engineering

kuspa@grad.hr

\section{Darko Barbalić, Neven Kuspilić}

\section{Trends of indicators of hydrological alterations}

For Indicators of Hydrological Alterations, nonparametric analysis of trend magnitude using Theil-Sen method and Mann-Kendall trend significance test has been performed in the Danube river basin in Croatia. Analysis have shown disturbing decreasing of May and June monthly flows resulting in extended low water season with possible negative impact on ecosystems and water usage. It is obvious that increase of water management resilience and adaptability is needed to fulfil more efficiently requirements of water users.

\section{Key words:}

Danube river basin, indicators of hydrological changes, trend analysis, Mann-Kendall test, trend significance

Prethodno priopćenje

\section{Darko Barbalić, Neven Kuspilić}

\section{Trendovi indikatora hidroloških promjena}

U radu se opisuje provedena analiza indikatora hidroloških promjena na slivu Dunava u Hrvatskoj primjenom neparametarskih metoda, i to Theil-Senovog procjenitelja veličine trenda te Mann-Kendallovog testa značajnosti trenda. Analizom su otkriveni zabrinjavajući trendovi smanjenja svibanjskih i lipanjskih protoka, koji na većem dijelu sliva znače produženje sezone malih voda što može uzrokovati značajne negativne posljedice kako za ekosustave tako i za korištenje voda. Vidljivo je da je nužno povećati otpornost i adaptibilnost upravljanja vodama na promjene ove vrste kako bi se što djelotvornije uspjele zadovoljiti potrebe korisnika vode.

Ključne riječi:

sliv rijeke Dunav, indikatori hidroloških promjena, analiza trenda, Mann-Kendallov test značajnosti trenda

Vorherige Mitteilung

Darko Barbalić, Neven Kuspilić

\section{Trends der Indikatoren hydrologischer Schwankungen}

In dieser Arbeit sind Analysen der Indikatoren hydrologischer Schwankungen des Donaubeckens in Kroatien durchgeführt. Dazu sind nichtparametrische Methoden, insbesondere die Trendstärkeschätzung nach Theil-Sen und der Trendtest nach MannKendall, angewandt. Unter anderem sind beunruhigende Trends eines reduzierten Durchflusses im Mai und Juni festgestellt, die zu einer verlängerten Tiefwassersaison führen, und somit bedeutende Folgen für das Ökosystem und die Wassernutzung haben können. Daher muss eine größere Widerstands- und Anpassungsfähigkeit im Wassermanagement vorgesehen werden, um trotz Schwankungen dieser Art, die Ansprüche der Wasserversorgung und des Ökosystems so effektiv wie möglich zu erfüllen.

Schlüsselwörter:

Donaubecken, Indikatoren hydrologischer Schwankungen, Trendanalyse, Mann-Kendall-Trendtest 


\section{Introduction}

For quite a long time, debates have been going on all over the world as well as in Croatia about possible changes of hydrological regime as a consequence of climate change, land use patterns change, overuse of water, and so on. These debates have gained momentum after several dry years, which were followed by extreme flood events from the year 2010 onwards. Throughout the world, changes of hydrological regime components have been examined intensively for several years now, and it would not be possible to reference all of them. However some references for larger regions in Europe and North America can be found in [1-8]. On the other hand, a small number of such analyses have been published in Croatia, and most of them concentrate on rather small regions $[9,10,11]$. In the framework of a more comprehensive study of hydrologic change indicators $[12,13]$, the analyses of their trends for the period extending over the past 30 years have been carried out for the Danube river basin in Croatia. Hydrologic changes, regardless of their causes, influence and modify the ecological status of water, the preservation of which is one of crucial water management tasks. The identification of importance of certain hydrological indices for the well-being of ecosystems, and the identification of their trends, enhances reliability of water management planning and provides for a more efficient water protection. At this moment, relationships between certain hydrological indices and biological elements of quality are not quite clear, although it can be generally stated that an increased alteration of natural state leads to higher hazards with regard to preservation of a good ecological status [14]. The analysis is progressing in two steps:

- Assessment to determine whether the hydrological regime component is significant and distinctive, dominant in the region of a certain ecosystem, when it is assumed that some biological communities are significantly dependent on its presence. On the other hand, if a hydrological parameter is naturally very variable, it is assumed that the existing biological communities have adapted to its variability and are less sensitive to its changes.

- Assessment to determine whether changes to certain parameters of hydrological regime indicate (in the long term) that an alteration leading to permanent deterioration of ecological status can be expected, and to identify measures by which such negative impact can be mitigated. It should be noted that assessment of a reliable link between hydrological alterations and their influence on ecosystems is a very complex and multidisciplinary research activity and, for that reason, this second step is beyond the scope of this paper. Nevertheless, results provided in this paper can be used as a basis for such research activities.

Consequently, the main purpose of indicators is to analyse and identify significant elements and alterations of hydrological regime influencing the maintenance and protection of ecological status. However, some of the indicators listed in this paper are commonly used in the standard hydrological practice as descriptors developed for water use and flood protection activities. Thus the results of this paper can also be used for the study of other aspects of water management.

\section{Data and methods}

Hydrologic change indicators $[12,13]$, Table 1, consist of 33 parameters that are considered to be very good descriptors of hydrological regime influencing the ecological status of water. In combination with the "Range of Variability Approach", they are regarded as one of the most frequently used hydrological methods for the assessment of hydrological alterations that can affect our ecosystems [15].

Table 1. Hydrologic change indicators

\begin{tabular}{|c|c|c|}
\hline \multicolumn{3}{|c|}{ INDICATORS OF HYDROLOGICAL ALTERATIONS $[12,13]$} \\
\hline INDICATOR & \multicolumn{2}{|c|}{ PARAMETER } \\
\hline $\begin{array}{l}\text { Magnitude } \\
\text { of monthly } \\
\text { water } \\
\text { conditions }\end{array}$ & $\begin{array}{l}1.0 \\
1.1 \\
1.2 \\
\cdots \\
1.11 \\
1.1\end{array}$ & $\begin{array}{l}\text { mean annual value* } \\
\text { mean value, January } \\
\text { mean value, February } \\
\text { mean value, November } \\
\text { mean value, December }\end{array}$ \\
\hline $\begin{array}{l}\text { Magnitude } \\
\text { and duration } \\
\text { of annual } \\
\text { extreme } \\
\text { water } \\
\text { conditions }\end{array}$ & & $\begin{array}{l}\text { annual } 1 \text { day minima } \\
\text { annual } 1 \text { day maxima } \\
\text { annual } 3 \text { day minima } \\
\text { annual } 3 \text { day maxima } \\
\text { annual } 7 \text { day minima } \\
\text { annual } 7 \text { day maxima } \\
\text { annual } 30 \text { day minima } \\
\text { annual } 30 \text { day maxima } \\
\text { annual } 90 \text { day minima } \\
\text { annual } 90 \text { day maxima }\end{array}$ \\
\hline $\begin{array}{l}\text { Timing of } \\
\text { annual } \\
\text { extreme } \\
\text { water } \\
\text { conditions }\end{array}$ & & $\begin{array}{l}\text { Julian date of annual maxima } \\
\text { Julian date of annual minima }\end{array}$ \\
\hline $\begin{array}{l}\text { Frequency } \\
\text { and duration } \\
\text { of high/low } \\
\text { pulses** }\end{array}$ & & $\begin{array}{l}\text { number of high pulses each year } \\
\text { number of low pulses each year } \\
\text { mean duration of high pulses within each year } \\
\text { mean duration of low pulses within each year }\end{array}$ \\
\hline $\begin{array}{l}\text { Rate/ } \\
\text { frequency } \\
\text { of water } \\
\text { condition } \\
\text { changes }\end{array}$ & & $\begin{array}{l}\text { means of all positive differences between con- } \\
\text { secutive daily values } \\
\text { means of all negative differences between } \\
\text { consecutive daily values } \\
\text { number of hydrological changes*** }\end{array}$ \\
\hline $\begin{array}{l}\text { This paran } \\
\text { included a } \\
\text { * Low pulse } \\
\text { the discha } \\
\text { when the } \\
\text { *** This indica } \\
\text { ogy (No. of }\end{array}$ & 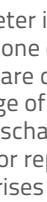 & $\begin{array}{l}\text { not listed in the original methodology. However, it is } \\
\text { the most common hydrological descriptors } \\
\text { fined as the period when the discharge is lower than } \\
5 \% \text { duration. High pulses are defined as the period } \\
\text { ge is higher than the discharge of } 25 \% \text { duration. } \\
\text { aces two indicators defined in the original methodol- } \\
\text { nd No. of falls) }\end{array}$ \\
\hline
\end{tabular}


The mathematical formulation of Hydrologic change indicators is given in this annex. Indicators belonging to the first and second groups represent parameters well known to the traditional hydrological practice (monthly means, and annual minima and maxima of several durations), and so these parameters are not explained in detail. On the contrary, additional examples are given for indicator groups 3, 4 and 5 based on the 1984 hydrograph of the Županja gauging station on the Sava River. The duration curve, required for low and high pulse thresholds (indicator group 4), was derived on the basis of a thirty-year period (from 1980 to 2009). Throughout this annex, the Iverson notation is used, where:

$[P]=\left\{\begin{array}{lll}1 & \text { for } & P=\text { True } \\ 0 & \text { for } & P \neq \text { True }\end{array}\right.$

Indicator group 1: Magnitude of monthly water conditions: Group 1 indicators represent monthly means, and they can be formulated as follows:

$I H A_{1, m}=\frac{1}{n} \sum_{i=1}^{n} Q_{i}$

where:

$I H A_{1, m}$ - indicator from group 1 , for month $\mathrm{m}\left(\mathrm{m}^{3} / \mathrm{s}\right)$

$M$ - ordinal number of month within a year, $1 \leq m \leq 12$

$n \quad$ - number of days in a month $m$

$Q_{i} \quad$ - daily average discharge $\left(\mathrm{m}^{3} / \mathrm{s}\right) i$-th day of $m$-th month

Indicator group 2: Magnitude and duration of annual extreme water conditions

Group 2 indicators represent yearly maxima and minima, with the duration of $1,3,7,30$ and 90 days. For minima:

$I H A_{2, m}=\min \left\{\frac{1}{n} \sum_{i=k}^{k+n-1} Q_{i}\right\} \quad \forall 1 \leq k \leq 365-(n+1)$

where:

$1 H A_{2, m}$ - indicator from group 2 for minima $\left(\mathrm{m}^{3} / \mathrm{s}\right)$, $m \in\{1,3,5,7,9\}$

$n \quad$ - duration (days), $n \in\{1,3,7,30,90\}$

$Q_{i} \quad$ - daily average discharge $\left(\mathrm{m}^{3} / \mathrm{s}\right) i$-th day of year

For maxima the definition is analogous:

$I H A_{2, m}=\max \left\{\frac{1}{n} \sum_{i=k}^{k+n-1} Q_{i}\right\} \quad \forall 1 \leq k \leq 365-(n+1)$

where:

$1 H A_{2, m}$ - indicator from group 2 for maxima $\left(\mathrm{m}^{3} / \mathrm{s}\right)$, $m \in\{2,4,6,8,10\}$

$n \quad$ - duration (days), $n \in\{1,3,7,30,90\}$

$Q_{i} \quad$ - daily average discharge $\left(\mathrm{m}^{3} / \mathrm{s}\right) i$-th day of year

Indicator group 3: Timing of annual extreme water conditions Two indicators of group 3 can be defined in following way:
$I H A_{3,1}=i\left[Q_{i}=Q_{\max }\right]$

$I H A_{3,2}=i\left[Q_{i}=Q_{\min }\right]$

where:

$I H A_{3,1}$ i $I H A_{3,2}$ - Indicators of hydrologic alteration from group 3

$i \quad$ - ordinal number of day within a year $(1 \leq i \leq 365)$

$Q_{i} \quad$ - daily average discharge $\left(\mathrm{m}^{3} / \mathrm{s}\right), i$-th day of year

$Q_{\max } \quad$ - maximal recorded daily average discharge $\left(\mathrm{m}^{3} / \mathrm{s}\right)$ during the year

$Q_{\min } \quad$ - minimal recorded daily average discharge (m3/s) during the year

$I H A_{3,1}$ and $I H A_{3,2}$ are shown in Figure 1.

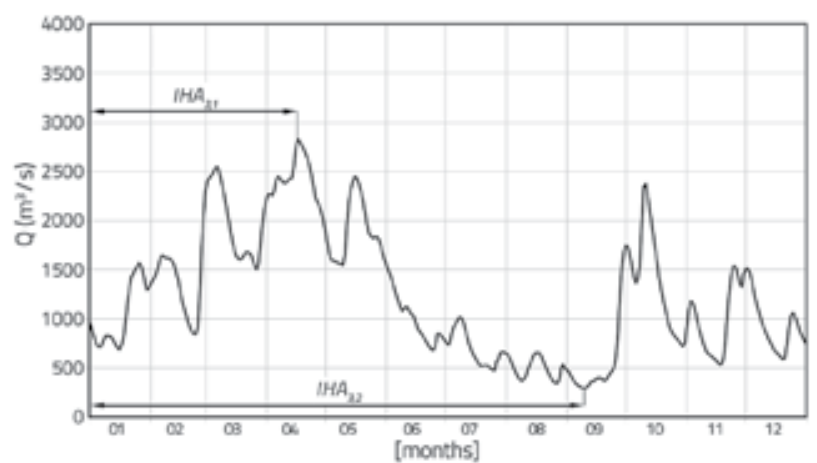

Figure 1. Hydrograph, with graphical definition of indicators $I H A_{3,1}$ and IHA $A_{3,2}$ for 1984

Indicator group 4: Frequency and duration of high/low pulses Four indicators of this group are defined as follows:

$$
\begin{aligned}
& I H A_{4,1}=\sum_{i=1}^{364}\left[Q_{i} \leq Q_{25 \%}<Q_{i+1}\right] \\
& I H A_{4,2}=\sum_{i=1}^{364}\left[Q_{i} \geq Q_{75 \%}>Q_{i+1}\right] \\
& I H A_{4,3}=\frac{1}{I H A_{4,1}} \sum_{i=1}^{365}\left[Q_{i}>Q_{25 \%}\right] \\
& I H A_{4,4}=\frac{1}{I H A_{4,2}} \sum_{i=1}^{365}\left[Q_{i}<Q_{75 \%}\right]
\end{aligned}
$$

where:

$1 H A_{4,1}$ i $/ H A_{4,2}$ - number of high and low pulses $1 H A_{4,3}$ i $/ H A_{4,4}$ - mean duration of high and low pulses (days)

$i \quad$ - ordinal number of day within a year $(1 \leq i \leq 365)$

$Q_{i} \quad$ - daily average discharge $\left(\mathrm{m}^{3} / \mathrm{s}\right)$, $i$-th day of year

$Q_{25 \%}$ - discharge of $25 \%$ duration ( $\mathrm{m}^{3} / \mathrm{s}$ )

$Q_{75 \%}$ - discharge of $75 \%$ duration ( $\mathrm{m}^{3} / \mathrm{s}$ )

Seven high and three low pulses, recorded during 1984, are depicted, together with their durations, in Figure 2. 

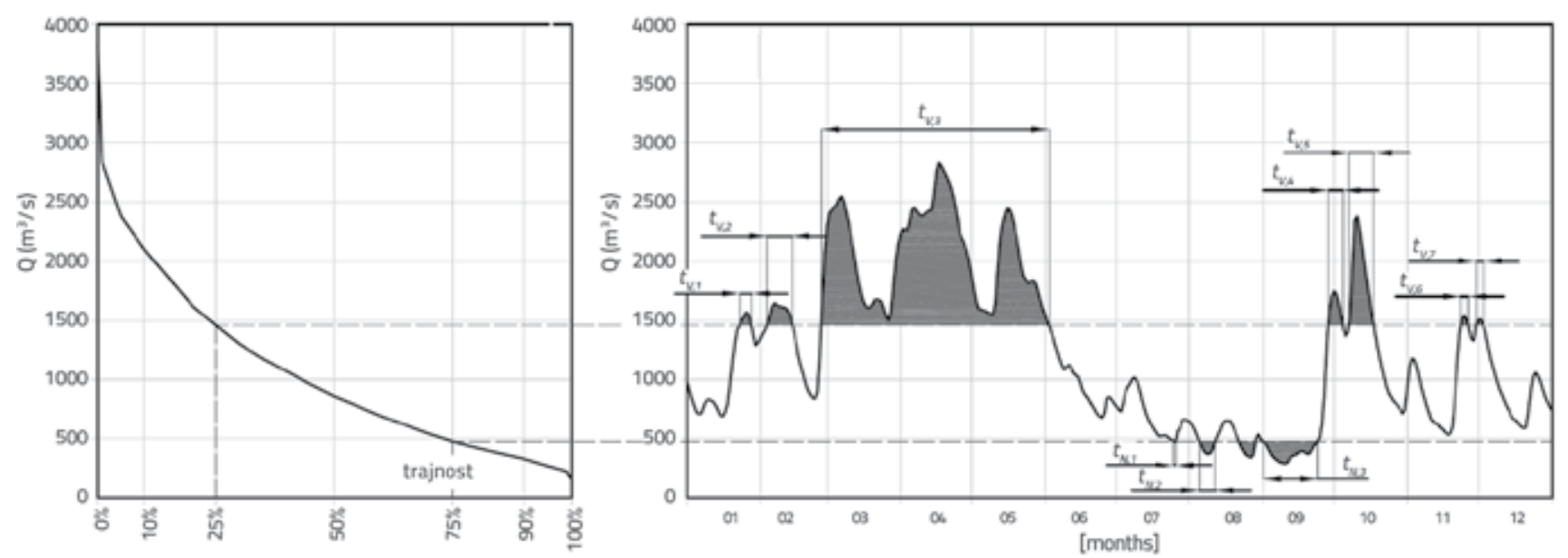

Figure 2. Duration curve and 1984 hydrograph with high and low pulses marked

Indicator group 5: Rate/frequency of water condition changes

Three indicators of this group are defined as follows:

$I H A_{5,1}=\frac{\sum_{i=1}^{364}\left(Q_{i+1}-Q_{i}\right)\left[Q_{i}<Q_{i+1}\right]}{\sum_{i=1}^{364}\left[Q_{i}<Q_{i+1}\right]}$
$I H A_{5,2}=-\frac{\sum_{i=1}^{364}\left(Q_{i+1}-Q_{i}\right)\left[Q_{i}>Q_{i+1}\right]}{\sum_{i=1}^{364}\left[Q_{i}>Q_{i+1}\right]}$

$I H A_{5,3}=\sum_{i=2}^{364}\left[\left(Q_{i+1}-Q_{i}\right)\left(Q_{i}-Q_{i-1}\right)<0\right]$

where:

$1 H A_{5,1} I H A_{5,2}$ - Indicators of group $5\left(\mathrm{~m}^{3} / \mathrm{s}\right)$

and $I H A_{5,3}$

$i \quad$ - ordinal number of day within a year $(1 \leq i \leq 365)$

$Q_{i}$ - daily average discharge $\left(\mathrm{m}^{3} / \mathrm{s}\right), i$-th day of year

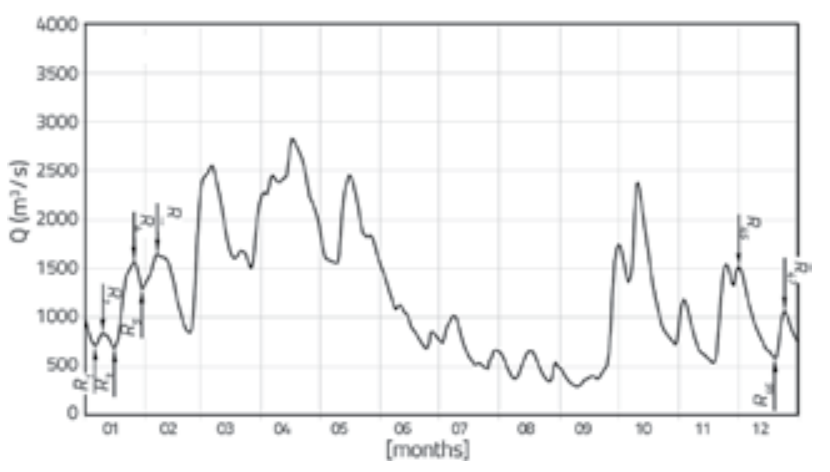

Figure 3. Hydrological changes recorded in 1984.

Many gauging stations that had an interruption of the recording due to war were included in the analysis, but only if it was possible to form time series of indicators with at least 25 members. Methods selected for trend analysis are
Hydrological changes $\left(R_{1}\right.$ to $\left.R_{47}\right)$ are shown in Figure 3.

The gauging stations from the Danube river basin, listed in the HIS 2000 hydrological database of the Croatian Meteorological and Hydrological Service have been included in the study. The analysis covering the thirty year period from 1980 to 2009 was conducted in order to assess recent changes, and to enable use of some of the results for the next River Basin Management Plans [16] which have to be developed in accordance with a very strict timetable.

Considering that some of the indicators describe hydrological phenomena that occur at the change of calendar years, and to avoid analysis errors, the start of the "calculation year" for indicator 3.1 was selected as described in [17].

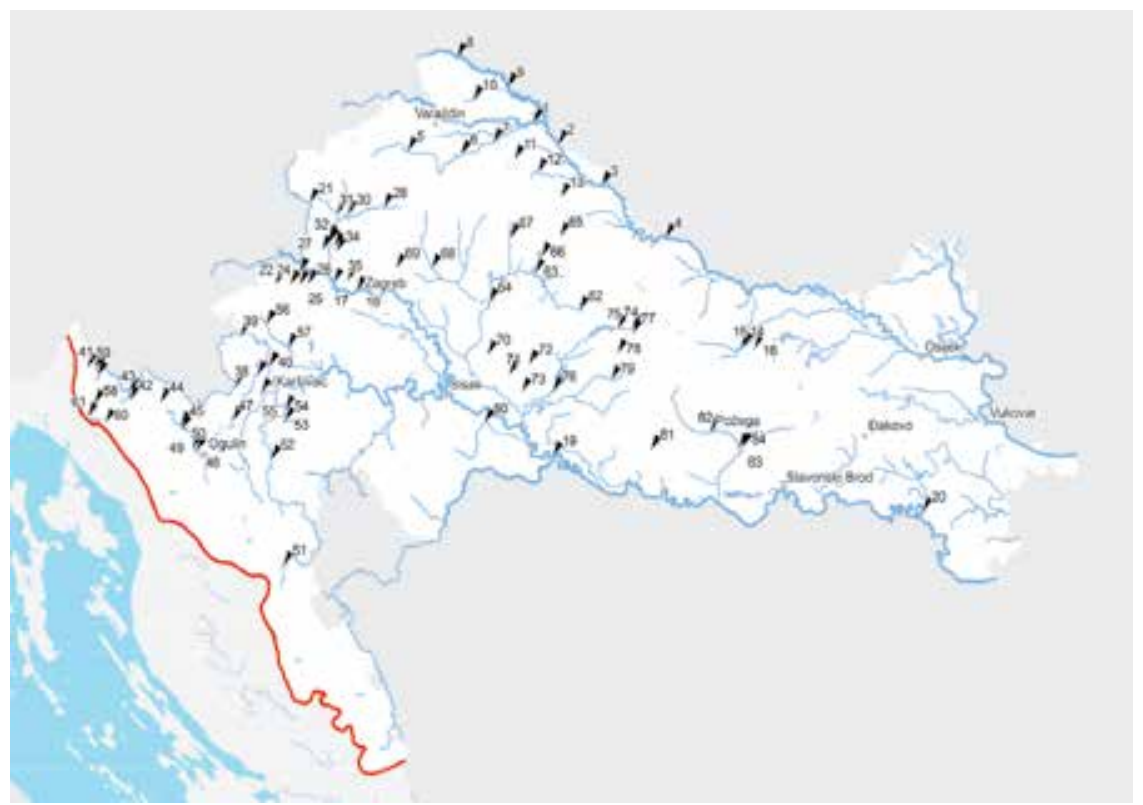

Figure 4. Location of gauging stations 
Table 2. List of gauging stations

\begin{tabular}{|c|c|c|c|c|c|}
\hline 1 & DONJA DUBRAVA, DRAVA & 29 & KUPLJENOVO, KRAPINA & 57 & LAZINA BRANA, KUPČINA \\
\hline 2 & BOTOVO, DRAVA & 30 & ZABOK STEPENICA, KRAPINICA & 58 & CRNI LUG, BELA VODA \\
\hline 3 & NOVO VIRJE-SKELA, DRAVA & 31 & GUBAŠEVO 1, HORVATSKA & 59 & SMREČJE STEPENICA, GEROVČICA \\
\hline 4 & TEREZINO POLJE, DRAVA & 32 & HRUŠEVEC, VUČELNICA & 60 & LOKVE, LOKVARKA \\
\hline 5 & ŽELJEZNICA, BEDNJA & 33 & JAKOVLJE, DEDINA & 61 & MRZLE VODICE, MRZLICA \\
\hline 6 & TUHOVEC, BEDNJA & 34 & DONJA BISTRA, BISTRA & 62 & PAVLOVAC, ČESMA \\
\hline 7 & LUDBREG, BEDNJA & 35 & ZAGREB, VRAPČAK & 63 & NARTA, ČESMA \\
\hline 8 & MURSKO SREDIŠĆE, MURA & 36 & KUPARI, KUPA & 64 & ČAZMA, ČESMA \\
\hline 9 & GORIČAN, MURA & 37 & HRVATSKO, KUPA & 65 & VELIKO TROJSTVO, BJELOVATSKA \\
\hline 10 & JENDRAŠIĆEK, TRNAVA & 38 & LADEŠIĆ DRAGA, KUPA & 66 & BJELOVAR, BJELOVATSKA \\
\hline 11 & MLAČINE, GLIBOKI POTOK & 39 & KAMANJE, KUPA & 67 & MARKOVAC, VELIKA RIJEKA \\
\hline 12 & KOPRIVNICA, KOPRIVNICA & 40 & BRODARCI, KUPA & 68 & LONJICA MOST, LONJA \\
\hline 13 & NOVIGRAD PODR., KOMARNICA & 41 & ZAMOST II, ČABRANKA & 69 & POPOVEC, KAŠINA \\
\hline 14 & MIKLEUŠ, VOĆINKA & 42 & IZVOR KUPICE, KUPICA & 70 & VLAHINIČKA, VLAHINIČKA \\
\hline 15 & ČAČINCI, VOJLOVICA & 43 & BROD NA KUPI, KUPICA & 71 & GRAČENICA, GRAČENICA \\
\hline 16 & ČAČINCI, KRAJINA & 44 & MORAVICE, DOBRA & 72 & KUTINSKE ČAIRE, KUTINA \\
\hline 17 & PODSUSED ŽIČARA, SAVA & 45 & LUKE, DOBRA & 73 & KUTINA, KUTINA \\
\hline 17 & SLUNJ UZVODNI, KORANA & 46 & TURKOVIĆI, GORNJA DOBRA & 74 & MUNIJE, ILOVA \\
\hline 18 & ZAGREB, SAVA & 47 & LEŠĆE TOPLICE, DOBRA & 75 & RAŠENICA, ILOVA \\
\hline 19 & JASENOVAC, SAVA & 48 & DONJE STATIVE, DOBRA & 76 & VELIKO VUKOVJE, ILOVA \\
\hline 20 & ŽUPANJA, SAVA & 49 & GOMIRJE, RIBNJAK & 77 & BASTAJI, RIJEKA \\
\hline 21 & ZELENJAK I, SUTLA & 50 & BRESTOVAC, VITUNJČICA & 78 & DARUVAR, TOPLICA \\
\hline 22 & KORETIĆI, BREGANA & 51 & LUKETIĆI, KORANA & 79 & BADLJEVINA UZVODNO, BIJELA \\
\hline 23 & BREGANA REMONT, BREGANA & 52 & VELJUN, KORANA & 80 & SUNJA, SUNJA \\
\hline 24 & SVINJARIĆI, BREGANICA & 53 & VELEMERIĆ, KORANA & 81 & CERNIK, ŠUMETLICA \\
\hline 25 & HAMOR, LIPOVAČKA GRADNA & 54 & TUŠILOVIĆ, RADONJA & 82 & POŽEGA, ORLJAVA \\
\hline 26 & SAMOBOR, GRADNA & 55 & MRZLO POLJE, MREÄNICA & 83 & PLETERNICA MOST, ORLJAVA \\
\hline 27 & PUŠĆA DONJA, PUŠĆA & 56 & STRMAC, KUPČINA & 84 & PLETERNICA, LONDĐA \\
\hline 28 & ZLATAR BISTRICA, KRAPINA & & & & \\
\hline
\end{tabular}

very robust and so they can be used for time series with gaps, which is why the missing data have not been filled in. Based on the described criterions, 84 gauging stations were selected for further analysis. Location of gauging stations is shown on Figure 4 while the list of gauging stations is shown in Table 2.

During the preliminary analysis of results, it was observed that an upgrade of measuring devices (water level recorder rods), operated on a substantial number of gauging stations during the analysed period, caused significant change in resulting values for certain indictors (this phenomenon is described in [18]). To avoid possible non-homogeneities induced by this phenomenon, daily time series were formed, after introduction of water level recorders, based on values recorded at 7 o'clock rather than based on the daily average of hourly records.

To gain information on hydrological regime alterations that do not result from direct human influence in the upstream zone (hydraulic structures and systems), additional analysis were made for the set of reference stations where natural regime was conditionally gauged. The information gathered during development of the first River Basin Management Plan (register of hydraulic structures and hydro-morphological alterations, [16]) was used as the basis for selection of gauging stations. As a negligible number of gauging stations within the watersheds is free from any anthropogenic alteration, the final screening was made based on an expert opinion, given that most significant alterations are caused by water storage facilities and large flood protection systems, while influence of small individual structures can be neglected (although they can cause deterioration of water status due to other reasons). The decrease of influence due to increase in distance was also taken into consideration, together with the cumulative effect of multiple structures and alterations to the upstream of national borders of Croatia.

Methods based on linear correlation have so far predominantly been used for trend significance analysis in the standard hydrological practice in Croatia. However, robust nonparametric methods are employed in this paper 
because the statistical distribution of indicators is unknown and time series have gaps. This is why trend magnitudes are calculated using the Theil-Sen estimate $[8,19,20]$ :

$\beta=\operatorname{Median}\left\{\frac{x_{i}-x_{j}}{t_{i}-t_{j}}\right\} \quad \forall i>j$

where:

$\beta$ - Theil-Sen estimate of trend magnitude

$x_{i}-i$-th element of time series

$t_{i}$ - time of record of $i$-th element of time series

$i, j$ - indexes.

The trend significance is calculated using the Mann-Kendall test. In this test, the null hypothesis of a statistically insignificant trend is defined as the nonexistence of monotonic change of a time series:

$H_{o}: p\left(x_{i}>x_{j}\right)=0,5 \forall i>j$

The Mann-Kendall statistics is calculated in the following way:

$S=\sum_{k=1}^{n-1} \sum_{j=k+1}^{n} \operatorname{sgn}\left(x_{j}>x_{k}\right)$

where:

S - Mann-Kendall statistics and:

$\operatorname{sgn}\left(x_{j}>x_{k}\right)=\left\{\begin{array}{l}+1 \text { for } x_{i}>x_{j} \\ 0 \text { for } x_{j}=x_{k} \\ -1 \text { for } x_{j}<x_{k}\end{array}\right.$

If a trend is not significant (no monotonic change), the expected value of statistics $S$ is 0 , and the variance equals:

$\operatorname{VAR}(S)=\frac{1}{18}\left[n(n-1)(2 n+5)-\sum_{p=1}^{q} t_{p}\left(t_{p}-1\right)\left(2 t_{p}+5\right)\right]$

where:

$q$ - number of tied groups

$t_{p}$ - number of elements in the $p$-th tied group

If the time series is long enough ( 25 and more elements), the Mann-Kendall statistics $S$ can be used for calculation of statistics $Z$ with the approximate normal distribution:

$Z=\left\{\begin{array}{r}\frac{S-1}{\sqrt{\operatorname{VAR}(S)}} \text { for } S>0 \\ 0 \text { for } S=0 \\ \frac{S+1}{\sqrt{\operatorname{VAR}(S)}} \text { for } S<0\end{array}\right.$

It should be noted that a statistically correct interpretation of the null hypothesis acceptance is not the proof of nonexistence of the trend, but rather the conclusion that "based on the available sample and pre-set confidence it cannot be concluded that trend exists". Such impossibility of drawing a definite conclusion is also typical for all other statistical tests. The standard $5 \%$ confidence has been accepted in this paper.
The existence of a statistically significant autocorrelation can considerably decrease reliability of trend significance tests. There are multiple approaches for extracting the actual trend from such time series that enable a more reliable assessment of its significance as published in several papers such as $[19,21,22]$ and others. Here, the TFPW (trend-free pre-whitening) procedure, explained in [19], and used in $[8,20]$ and many other papers, is used. The procedure consists of following steps:

1. Theil-Sen estimate of trend magnitude $\beta$ is calculated by using recorded time series

2. Trend is removed based on equation $x_{i}^{\prime}=x_{i}-\beta t_{i}$ where $x_{i}^{\prime}$ is the $i$-th element of time series with trend removed

3. Serial correlation coefficient with step $1, r_{1}$ of time series $\left\{x^{\prime}\right\}$ is calculated and its significance is assessed (5\%)

Based on the first three steps:

a) If $r_{1}$ is not statistically significant, the trend significance is analysed using the original recorded time series $\{x\}$,

b) If $r_{1}$ is statistically significant, the trend significance is analysed using the time series $\left\{x^{\prime \prime}\right\}$ from which the influence of autocorrelation is removed by the following equation $x_{i}^{\prime \prime}=x_{i}^{\prime}-r_{1} x_{i-1}^{\prime}+\beta t_{i}$.

After application of the described analysis, significant trends of some indicators have appeared on an unexpectedly large number of gauging stations. On the other hand, it obviously can not be concluded that time series recorded at all gauging stations are completely statistically independent. So the question was asked if a certain number of gauging stations with (local) trends recorded are representative for the larger area (region). In other words, the question is: what is the possibility to record, independently and by pure chance, significant trends on a certain number of gauging stations.

To assess this, the method of field (global) significance, described in $[4,23]$ was employed. In this respect, a random sampling from the recorded time series was performed in the same way for all stations in the region, which resulted in the establishment of a large number of groups (here 2,000 groups) of time series with properties comparable to recorded ones. As the sampling was performed in the same order for all stations, the level of their correlation was preserved. After that, the number of gauging stations with significant trends was counted for each sampled group of time series, and the empirical distribution was formed. Based on this empirical distribution, the probability of occurrence of such number of gauging stations with significant trends can be evaluated. Probability of $5 \%$ was selected in this paper. It should be noted that such empirical distribution can be used only for the sample from which it was derived. This analysis was applied for both positive and negative trends. 
Furthermore, the magnitude of trends from the recent period was compared to magnitudes of trends that occurred in the previous 30-year periods, for the mean annual and mean monthly flows of the indicator group 1 . In other words, it was assessed whether trends with higher magnitudes were recorded since the beginning of the gauging.

\section{Results}

The explained methodology, depending on the indicator selected, was used to calculate results for 72 to 84 (78 in average) gauging stations.

If the autocorrelation influence is not taken into consideration, the results are as follows (Figures 5 to 8). In most cases, the autocorrelation was not statistically significant, while the significance was more pronounced for the indicators related

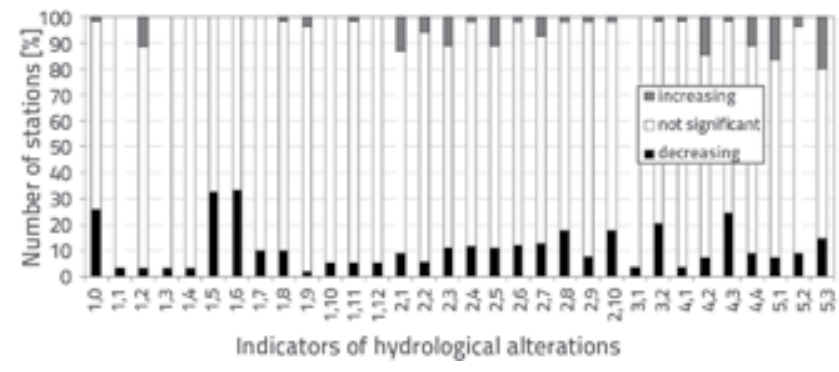

Figure 8. Significant trends on gauging stations with minor anthropogenic alteration (percentage of stations)

to low flows, as expected (Figure 9). After application of the TFPW procedure, the results are slightly changed (Figures 10 to 13). The spatial distribution of gauging stations with statistically significant trends for certain indicators is shown on Figures 14 to 19.

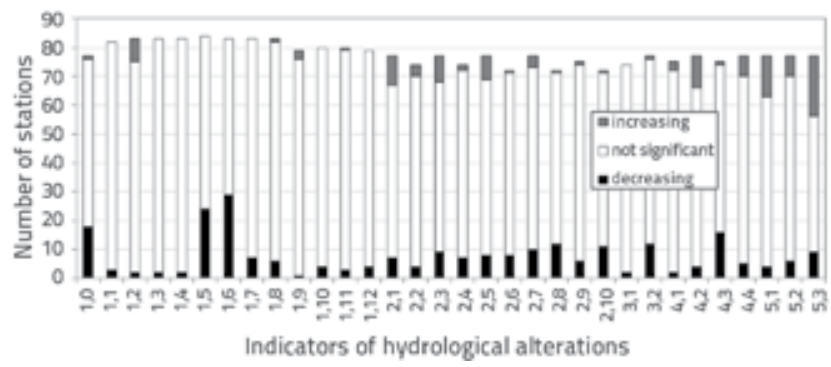

Figure 5. Significant trends on all gauging stations (number of stations)

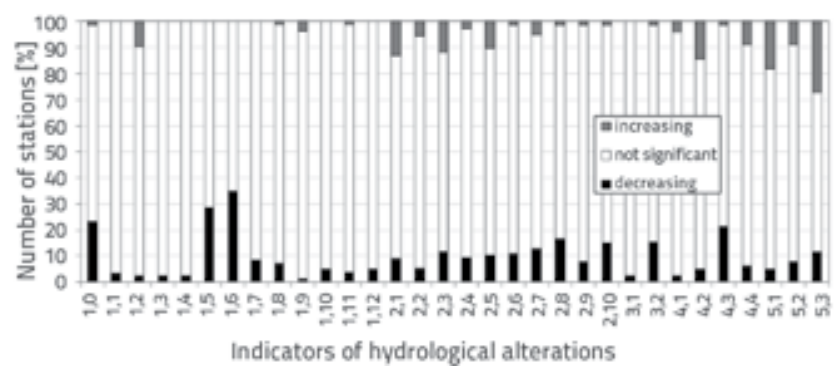

Figure 6. Significant trends on all gauging stations (percentage of stations)

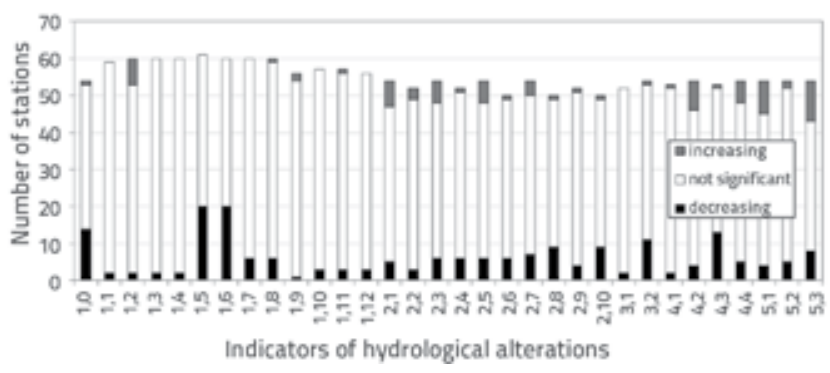

Figure 7. Significant trends on gauging stations with minor anthropogenic alteration (number of stations)

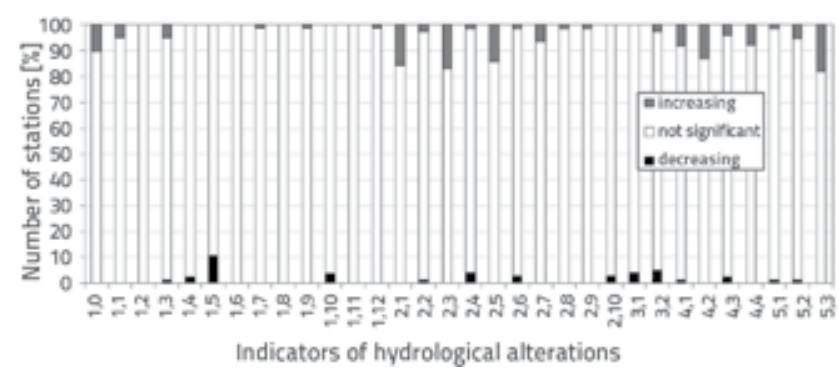

Figure 9. Number of gauging stations with statistically significant (5 $\%$ ) autocorrelation coefficients

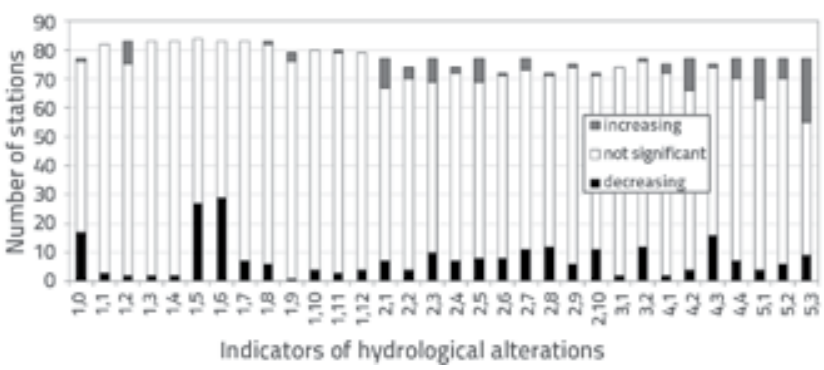

Figure 10. Statistically significant trends on all gauging stations after application of TFPW (number of stations)

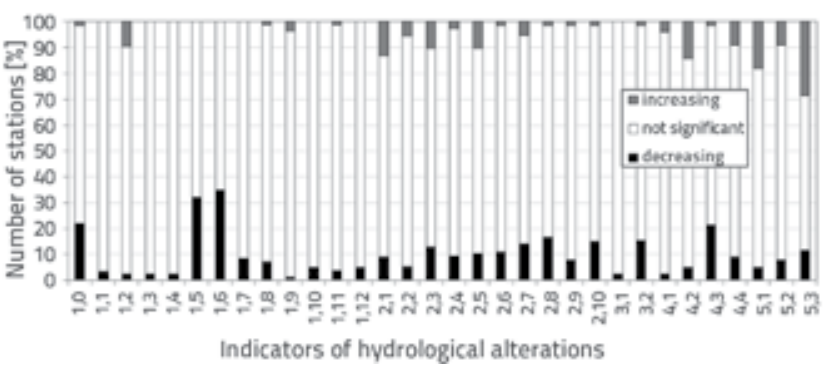

Figure 11. Statistically significant trends on all gauging stations after application of TFPW (percentage of stations) 


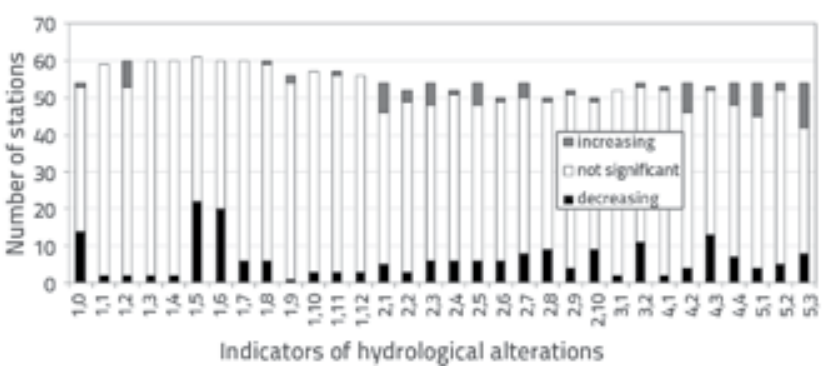

Figure 12. Statistically significant trends on gauging stations with minor anthropogenic alteration, after application of TFPW (number of stations)

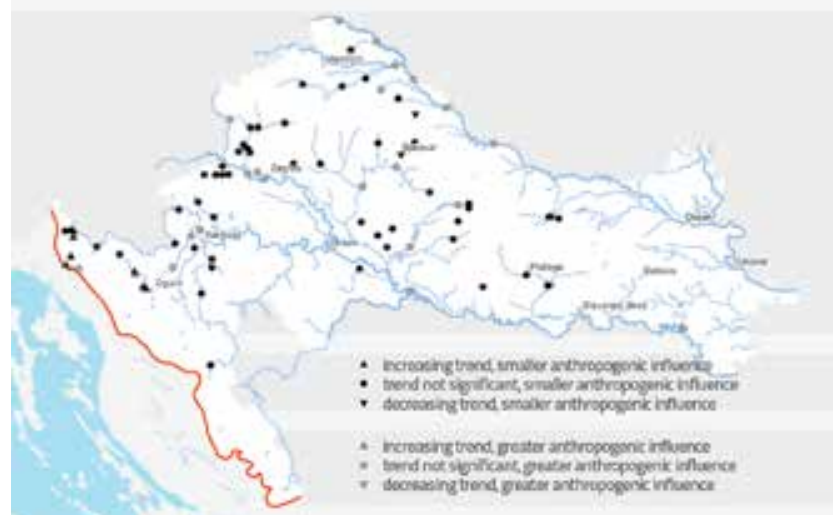

Figure 14. Mean annual discharges (indicator 1.0)

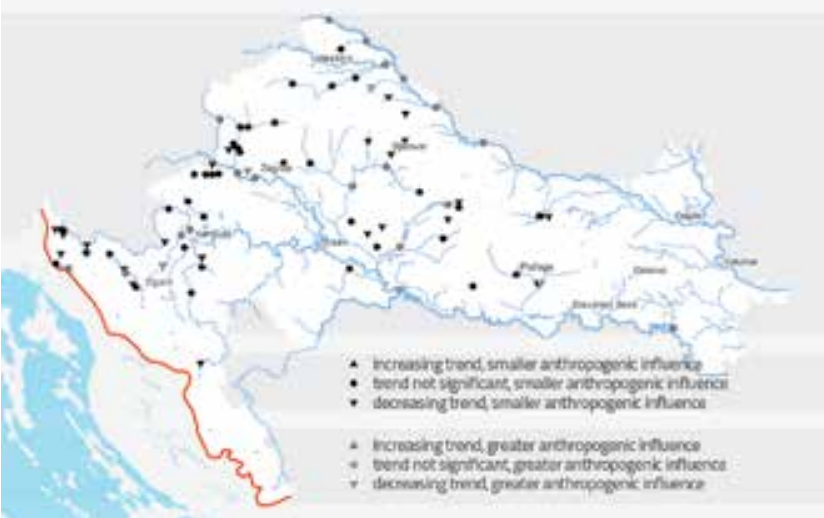

Figure 16. Mean May discharges (indicator 1.5)

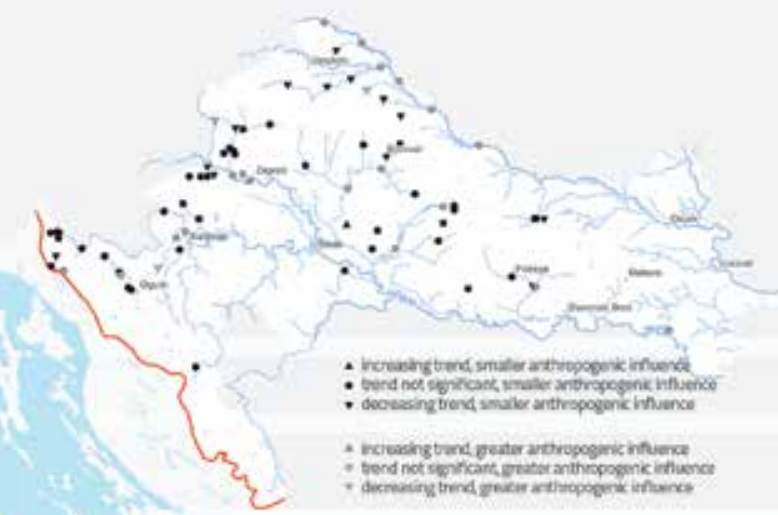

Figure 18. Duration of high pulses (indicator 4.3)

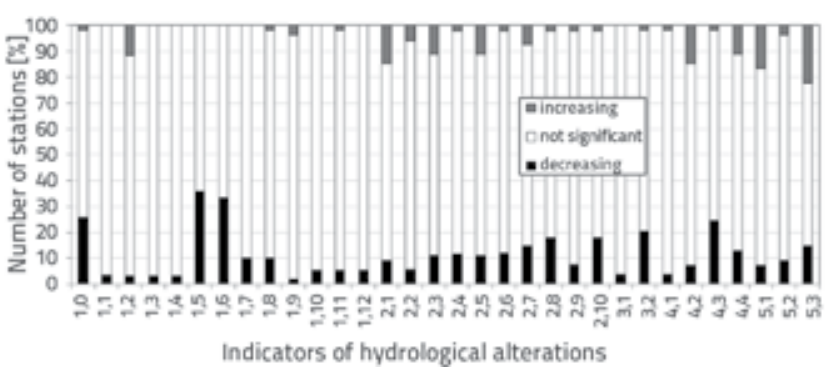

Figure 13. Statistically significant trends on gauging stations with minor anthropogenic alteration, after application of TFPW (percentage of stations)

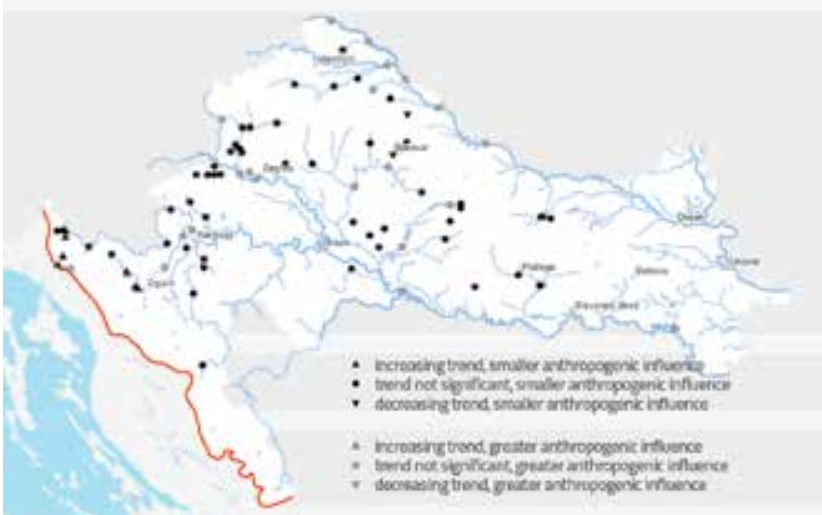

Figure 15. Mean February discharges (indicator 1.2)

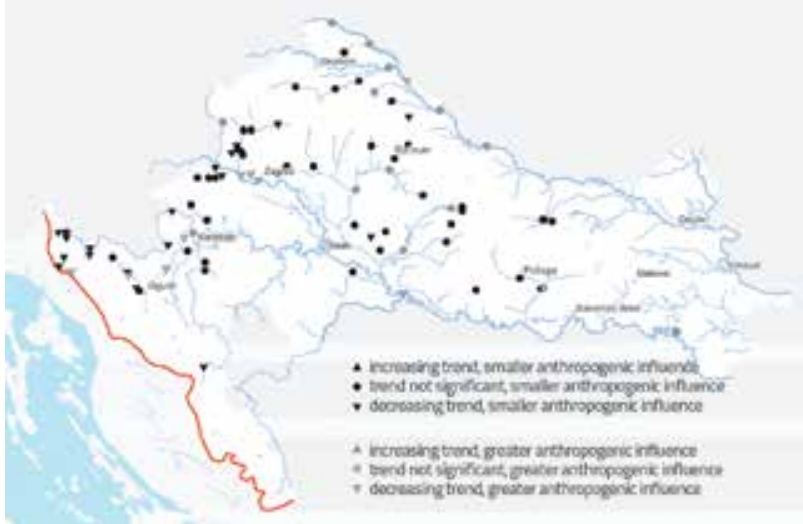

Figure 17. Mean June discharges (indicator 1.6)

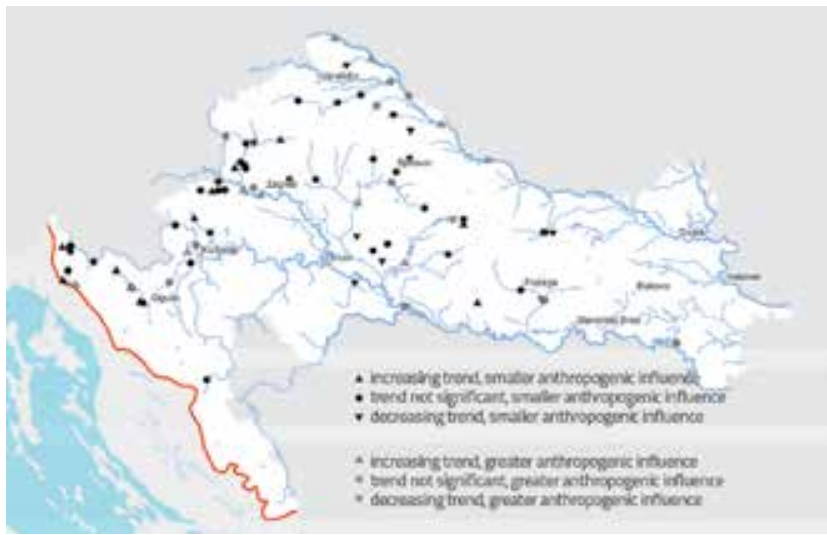

Figure 19. Number of hydrological changes (indicator 5.3) 


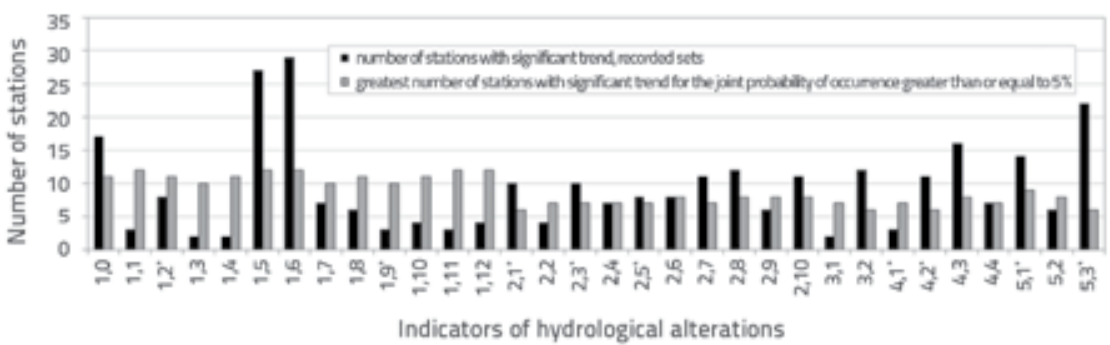

Figure 20. Relation of recorded and statistically significant numbers of trends

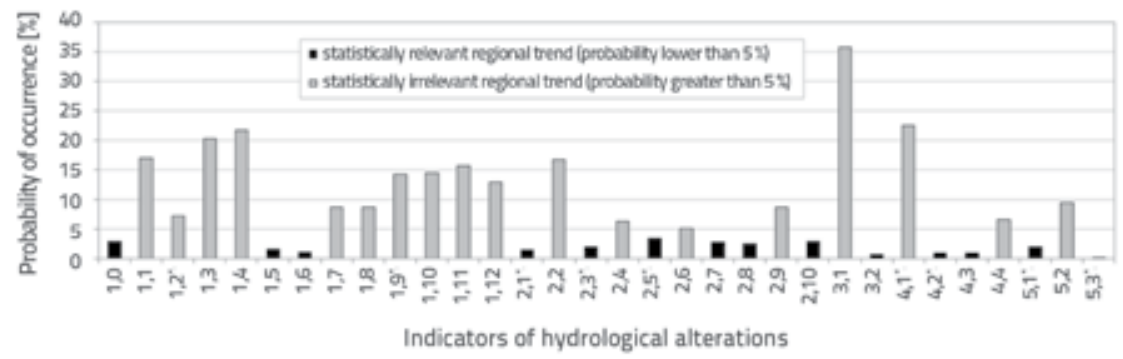

Figure 21. Empirical probability of occurrence of recorded regional trend, with its statistical significance level

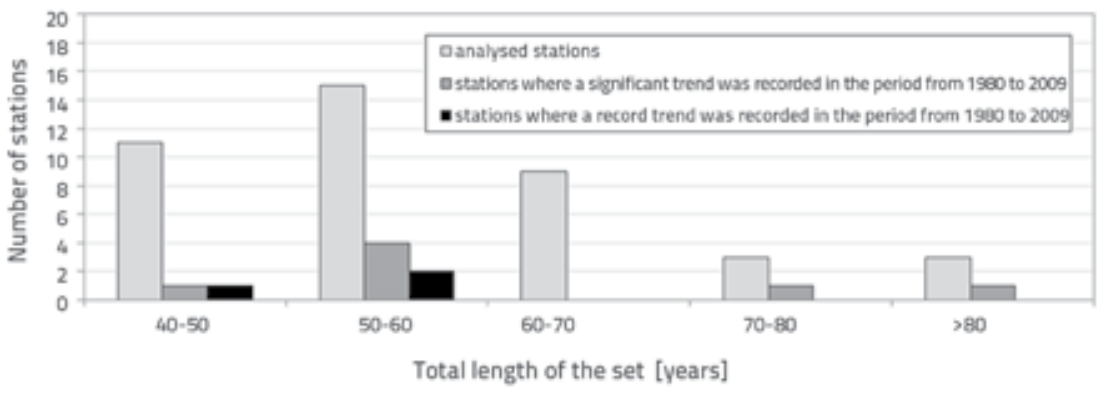

Figure 22. Maximum trends, annual mean discharges

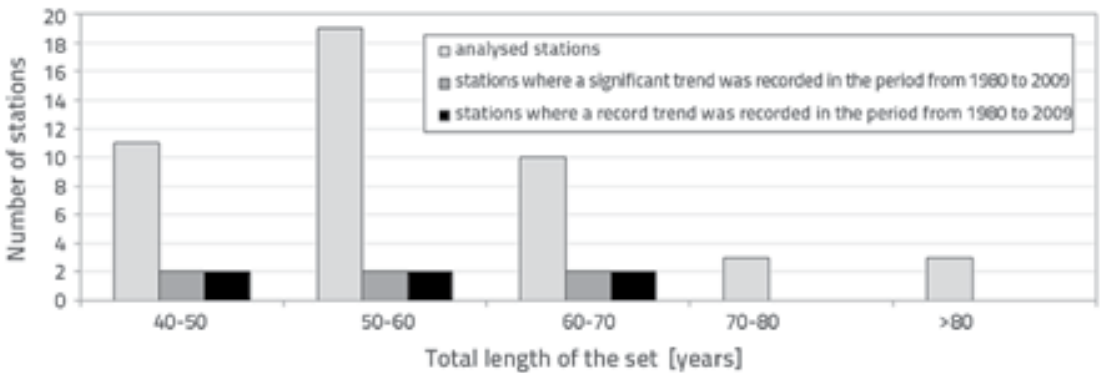

Figure 23. Maximal trends, February mean discharges

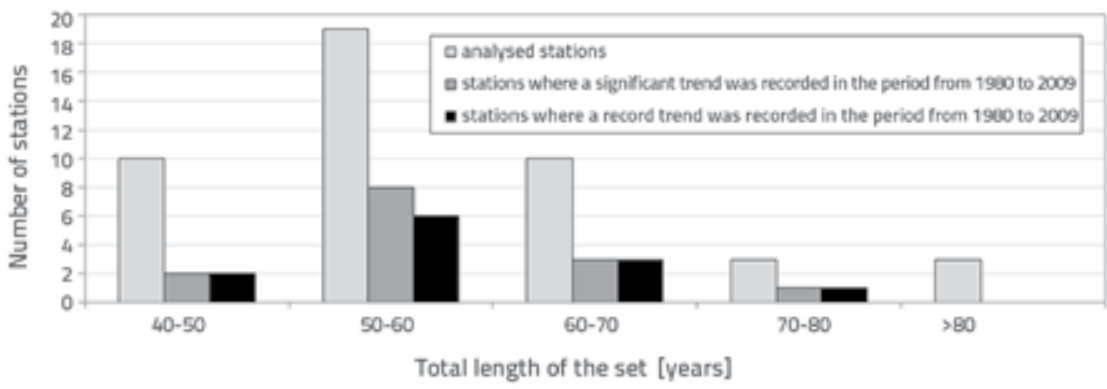

Figure 24. Maximal trends, May mean discharges
The number of gauging stations with recorded significant trends, as well as the number of stations where significant trends are required in order to get regional probability of less than $5 \%$, is shown at Figure 20. Decreasing trend results are shown by default, except for the cases where increasing trends were significant. These indicators are marked with asterisk.

It should be emphasised that both increasing and decreasing trends had regional significance for indicators 2.3, 2.5, and 5.3. The empirical probability of recorded trend with its significance is shown in Figure 21 (increasing trends are marked by asterisk).

In addition, the recent trend magnitude was compared to trend magnitudes recorded in a more distant past. Unfortunately, the measurement quality, as well as number of time series, decrease significantly as we go back in time. For example, daily time series longer than 80 years without significant interruptions are available for just several gauging stations at large rivers (Sava, Mura, and Drava). For that reason, the analysis was performed for the annual, February, May, and June mean discharges. Any incidence of past 30-year periods with statistically significant trends having higher magnitude then those recorded in the recent 30-year period was established. Results are summarised at Figures 22 to 25.

It can be see from Figures 22 to 25 that the trend with highest magnitude was recorded in the period from 1980 to 2009 and for mean May discharges on only one of the gauging stations with time series longer than 70 years. The recent trends had the highest magnitude on almost all stations with time series from 40 to 70 years on which significant trend for May and February mean discharge were recorded in period from 1980 to 2009. On the other hand, recent trends for annual and June means are not so extreme.

The change of trends over time is depicted in Figures 26-29 for gauging stations with the longest time series 
(over 80 years) and without significant data gaps. The trends are displayed with reference to the last year of period for which the trend was calculated.

Even though the number of stations with long time series is very limited and inadequate for statistical inference, it seems that certain sequences are visible, with phases significantly longer than 30 years and with span of approximately $-2.5 \%$ to $+2.5 \%$ per year (Figures 26-29).

\section{Conclusion}

The analysis of trends of hydrologic change indicators in the Danube river basin in Croatia was conducted for a recent 30-year period in the scope of this paper. The robust Mann-Kendall nonparametric test was applied, the influence of autocorrelation on the assessment of trend significance was removed using the TFPW method, and the regional significance of trends was assessed. It should be noted that the reference period was very vibrant from the hydrometric point of view due to interruption in time series measurements caused by the war on the one side, and introduction of new measurement technology (transfer from gauging rods to water level recorders) on the other.

The analyses showed especially alarming negative trends for May (indicator 1.5) and June (indicator 1.6) discharges which, for the main part of the river basin, mark an earlier start and prolongation of the period of low flows. This can result in significant negative impacts, not only for the well-being of ecosystems but for the water usage (for example irrigation) as well. The annual average values were considerably influenced by these trends (indicator 1.0). An increase in February flows was noted at eight gauging stations in Gorski Kotar (upper drainage basin of the Dobra and Kupa rivers), but that increase is not regionally significant for the entire Danube river basin in Croatia. The mean duration of high pulses (events with discharge higher

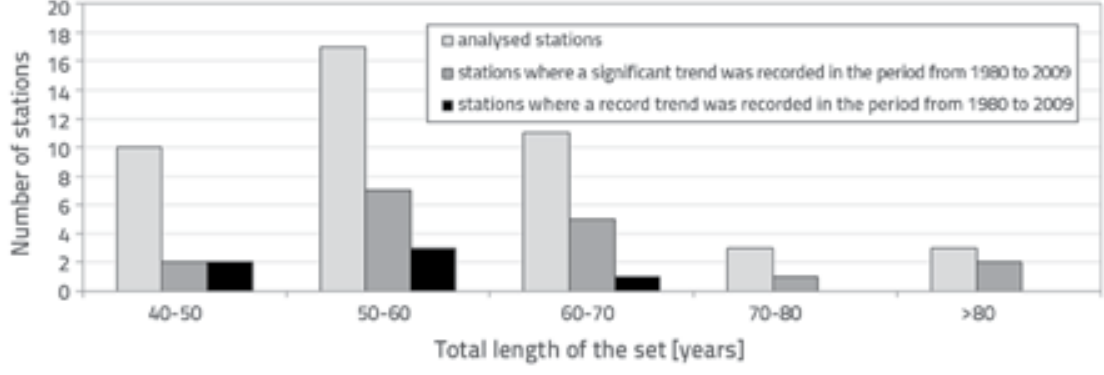

Figure 25. Maximal trends, June mean discharges

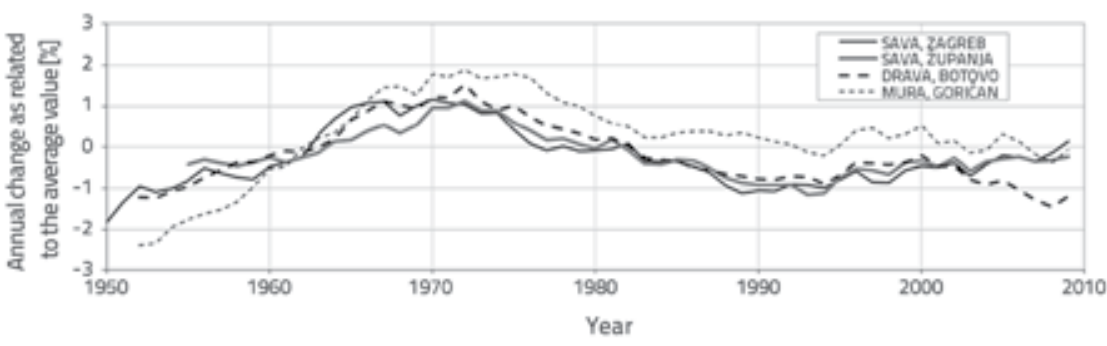

Figure 26. Change of trends over time, annual mean discharges

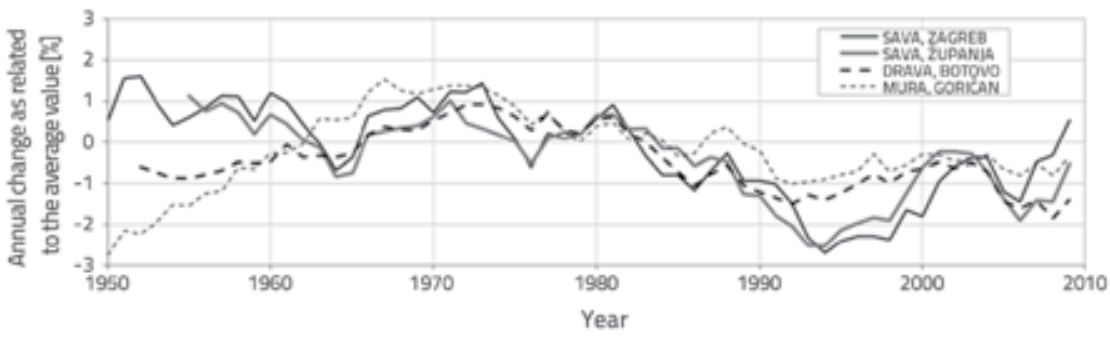

Figure 27. Change of trends over time, mean February discharges

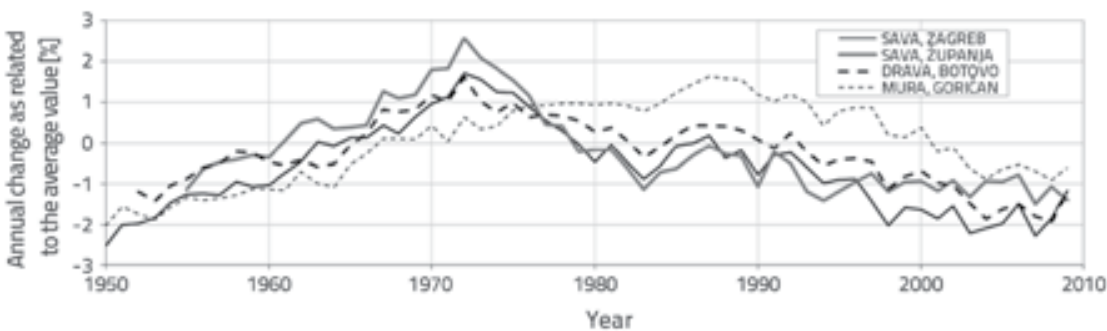

Figure 28. Change of trends over time, mean May discharges

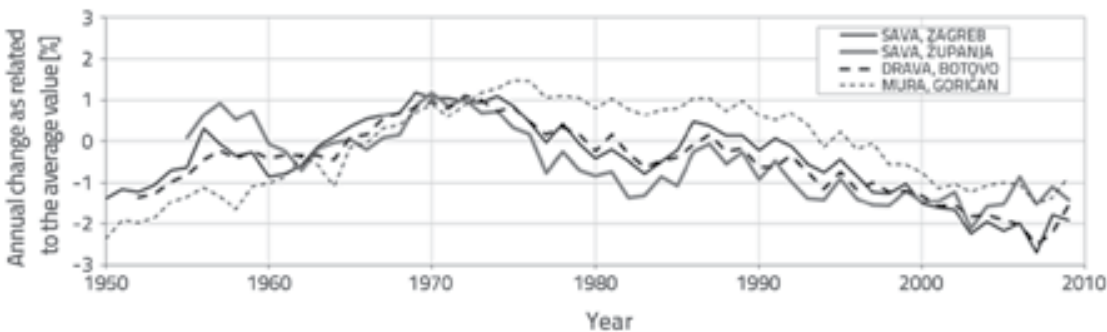

Slika 29. Hod trendova srednjih mjesečnih protoka, lipanj, stanice s dugim nizovima 
than discharge of $25 \%$ duration, indicator 4.3 ) is increasing, as well as an average hydrograph rate of rise (indicator 5.1) and the number of hydrological changes (indicator 5.3). In line with the above statements, the decrease of mean flows of high and low water events is significant (indicators 2.3, 2.5, $2.7,2.8,2.10)$. All these indicators point to an increase in low flow periods during the summer, and to a higher hydrograph dynamism.

Contrary to global picture, there is a regionally significant number of gauging stations where an increase of mean flows of low water events (indicators 2.1, 2.3 and 2.5), and a decrease in the number of hydrological changes (indicator 5.3), was recorded.

The question can be put about the real reason for the changes detected in this study. As only the chain of processes was analyzed, final conclusions are not possible. Nevertheless, most of the changes are well-matched with often used climatic-change scenarios, which foresee an increase in droughts, and more intensive and more frequent extreme events (as in [24] for example). Also, effects of urbanization can increase runoff and reduce retention time of water in basins, which is compatible with the results of our analysis. Taking all this into account, it is obvious that an alteration to hydrological regime was detected, although an exact source of such change can not be determined. Whatever the reasons, it is obvious that the resilience and adaptability of water management to such disturbances must be increased so that we can continue meeting, as efficiently as possible, the needs of water users and ecosystems dependent on water.

Hydrologic change indicators, defined in $[12,13]$ and examined in this paper, are based on discharge. It should be borne in mind that these indicators are not a definitely fixed set of indicators but rather one of the most complete sets. The indicators based on water level and depth are also highly relevant for the analysis of hydro-morphological status and alterations, and so further research should be oriented in that direction as well, especially because a significant fund of data is already in place (HIS 2000).

In addition, a higher emphasis must also be placed on hydrological monitoring activities, especially in the sense of spatial distribution, so that more efficient and prompt actions can be taken, because of obvious unbalanced density of gauging stations which are mostly missing in the eastern part of the basin where greatest conflicts in water management are expected (agriculture - ecosystems).

\section{REFERENCES}

[1] Kundzewicz, Z.W., Graczyk, D., Maurer, T., Przymusinska, I. Radziejewski, M., Svensson, C., Szwed, M.: Detection of change in world-wide hydrological time series of maximum annual flow, Report 32, GRDC Report Series, 2004.

[2] McCabe, G.J., Wolock, D.M.: A step increase in streamflow in the conterminous United States, Geophysical Research Letters, Vol. 29, NO. 24, 2185, doi:10.1029/2002GL015999, 2002.

[3] Douglas, E.M., Vogel, R.M., Kroll, C.N.: Trends in Foods and low Fows in the United States: impact of spatial correlation, Journal of Hydrology 240 (2000), pp. 90-105, 2000

[4] Burn, D.H., Hag Elnur, M.A.: Detection of hydrologic trend and variability. J. Hydrol. 255, pp. 107-122, 2002

[5] Pekarova, P., Miklanek, P., Pekar, J.: Long-term trends and runoff fluctuations of European rivers, Climate Variability and ChangeHydrological Impacts (Proceedings of the Fifth FRIEND World Conference held at Havana, Cuba, November 2006), IAHS Publ. $308,2006$.

[6] Wang, W., Van Gelder, P.H.A.J.M., Vrijling, J.K.: Trend And Stationarity Analysis For Stareamflow Processes Of Rivers In Western Europe In The 20th Century, IWA International Conference on Water Economics, Statistics, and Finance, Rethymno, Greece, 8-10 July 2005.

[7] Bormann, H.: Runoff Regime Changes In German Rivers Due To Climate Change, Erdekunde, Vol. 64 · No. 3, pp. 257-279, 2010
[8] Danneberg J.: Changes in runoff time series in Thuringia, Germany - Mann-Kendall trend test and extreme value analysis, Advances in Geosciences, 31, pp. 49-56, 2012.

[9] Trninić, D., Bošnjak, T.: Karakteristični protoci Save kod Zagreba, Hrvatske vode 17 (2009) 69/70, pp. 257-268, 2009.

[10] Gajić-Čapka, M., Cesarec, K.: Trend i varijabilnost protoka i klimatskih veličina u slivu rijeke Drave, Hrvatske vode 18 (2010), 71, pp. 19-30, 2009.

[11] Bonacci, O., Oskoruš, D.: The changes in the lower Drava River water level, discharge and suspended sediment regime, Environmental Earth Sciences, Volume 59, Issue 8, pp. 16611670, February 2010.

[12] Richter, B., Baumgartner, J., Powell, J., Braun, P.: A Method for Assessing Hydrologic Alteration within Ecosystems, Conservation Biology, Volume 10, No 4, 1996.

[13] Richter, B., Baumgartner, J., Wigington, R., Braun, P.: How much water does a river need?, Freshwater Biology 37, 231-249, 1997.

[14] Poff, N.L., Zimmerman, J.K.H.: Ecological responses to altered flow regimes: a literature review to inform the science and management of environmental flows, Freshwater Biology 55, pp. 194-205, 2010.

[15] Tharme, R.E.: A Global Pespective on Environmental Flow Assessment: Emerging Trends in the Development and Application of Environmental Flow Methodologies for Rivers, River Research and Applications 19, pp. 397-441, 2003. 
[16] Plan upravljanja vodnim područjima, Vlada Republike Hrvatske, 2013.

[17] Barbalić, D., Petraš, J.: Seasonal occurrence of maximum annual flows in the Danube river basin in Croatia, GRAĐEVINAR 64 (2012) 1, pp. 33-38.

[18] Bušelić, G., Rubinić, J.: Problems with Consistency of Hydrological Data Series Caused By Different Time Discretization Used in Their Primary Analysis, 2006.

[19] Yue, S., Pilon, P., Phinney, B., Cavadias, G.: The influence of autocorrelation on the ability to detect trend in hydrological series, Hydrological Processes 16, pp. 1807-1829, 2002.

[20] Burn, D.H., Cunderlik, J.M., Pietroniro, A.: Hydrological trends and variability in the Liard River basin, Hydrological SciencesJournal-des Sciences Hydrologiques, 49 (1), 53-67, 2004.
[21] McBride, G.B.: Using Statistical Methods for Water Quality Management: Issues, Problems and Solutions, A John Wiley \& sons, 2005

[22] Bayazit, M., Önöz, B.: To prewhiten or not to prewhiten in trend analysis?, Hydrological Sciences Journal, 52:4, pp. 611-624, 2007.

[23] Livezey, R.E., Chen, W.Y.: Statistical field significance and its determination by Monte Carlo techniques, Monthly Weather Rev. 111, pp. 46-59, 1983.

[24] Climate Change 2014: Impacts, Adaptation, and Vulnerability, Volume II: Regional Aspects, Europe, IPPC Working Group II Contribution to the IPCC 5th Assessment Report, Accepted Unedited Final Draft Report, 2014 